\title{
Symboliczne znaczenie roślin uprawianych w tradycyjnej zagrodzie
}

\section{The symbolic meaning of plants grown in a traditional homestead}

\begin{abstract}
Streszczenie
Zieleń w tradycyjnej zagrodzie tak, jak w każdym innym środowisku, spełniała trzy podstawowe grupy funkcji: ochronno-techniczną, użytkową i społeczno-kulturową. Spełniała, ponieważ od końca XX w. obserwujemy zanikanie zagrody jako rozwiązania przestrzennego charakteryzującego zabudowę wsi, a za tym i zanikanie specyficznych funkcji towarzyszącej jej zieleni. Zieleń w zagrodzie, dzięki swoim wartościom użytkowym, izolacyjnym, regulacyjnym i biologicznym wywiera znaczny wpływ na warunki życia i ludzi i zwierząt. Pełniła przede wszystkim funkcję użytkową, w tym produkcyjną i ochronną. Jednak nie można nie uwzględniać jej roli społeczno-kulturalnej; przede wszystkim ozdobnej, ale też symbolicznej. Indywidualne cechy roślin użytkowanych w zagrodach znajdowały odpowiednie zastosowanie dla właściwego ich miejsca, funkcji i roli. Miały one, wywodzące się zazwyczaj z racjonalnych źródeł, określone znaczenie symboliczne, które współcześnie jest często, mniej lub bardziej świadomie, kontynuowane.
\end{abstract}

\begin{abstract}
Greenery in the traditional croft, as in any other environment, served three basic groups of functions, i.e. protective and technical, utilitarian as well as social and cultural. It did serve but since the late $20^{\text {th }}$ century we have been observing the decline of croft as a spatial solution characterising the rural development and thus the decline of the specific functions of its accompanying greenery. Due to its utilitarian, isolating, regulating and biological properties, greenery in the croft has a considerable effect on people's and animals' living conditions. It primarily served the utilitarian function, which included production and protection. One must not, however, fail to take into consideration its social and cultural role, above all ornamental but also symbolic. The individual features of plants utilised at crofts found appropriate application in the right place, function and role. They had a specific symbolic meaning, which usually stemmed from rational sources and which is more or less consciously perceived even today.
\end{abstract}

Słowa kluczowe: wieś, tradycyjna zagroda, zieleń, symbolika

Keywords: village, traditional homestead, green, symbols

\section{Wprowadzenie}

Rośliny uprawiane w tradycyjnej zagrodzie dzięki swoim wartościom użytkowym, izolacyjnym, regulacyjnym i biologicznym wywierały znaczny wpływ na warunki środowiskowe. Pełniły przede wszystkim funkcję użytkową, a w tym tak produkcyjną, jak i ochronną, ale nie można nie uwzględniać ich roli społeczno-kulturalnej; przede wszystkim ozdobnej, ale i też symbolicznej. Symbolizm zieleni wywodzący się zazwyczaj z racjonalnych źródeł, znajdował i niekiedy nadal znajduje swoje przełożenie w obrzędach i obyczajach.

Zarówno użytkowym, jak i dekoracyjnym elementem tradycyjnego gospodarstwa wiejskiego, tak rezydencjonalnego, jak i chłopskiego był ogród przydomowy z przedogródkiem, ogrodem kwiatowym, zielnym i warzywnikiem. Za pierwsze ogrody chłopskie można uważać działki przyzagrodowe przy-

\section{Introduction}

Plants grown at the traditional croft had a considerable effect on the environmental conditions due to their utilitarian, isolating, regulating and biological properties. They predominantly served the utilitarian function, which included production and protection, but one must not fail to take into consideration their social and cultural role, above all ornamental but also symbolic. The symbolism of the greenery, usually stemming from rational sources, found and occasionally still finds its refection in rituals and customs.

A both utilitarian and decorative element of the traditional rural homestead, both residential and peasant, was a backyard garden with a foregarden, a flower garden, an herb garden and a vegetable garden. The first peasant gardens can be traced back to farm allotments allocated to landless peasants in the $13^{\text {th }}$ century. Four crop groups could 
dzielane bezrolnym chłopom w XIII w. Wyróżnić w nich można bylo cztery zespoly upraw. Warzywnik, zielnik, sad i gaj'. To zielnik przekształcił się w późniejszych okresach w umieszczane symetrycznie przy wejściu na działkę: ogródek kwiatowy i/lub ziołowy. Sad był częścią użytkową ogrodu, która stanowiła odrębną całość. Charakterystycznym, dawnym obszarem zieleni przydomowej był gaj, zwany również gaikiem. Wykorzystywane do wypoczynku miejsce poróniete murawa i ocienione lipami, debami, jesionami, jaworami czy też wa i iñjem nazyano też róże formy skupisk ziel i krzewami. które zazyczaj zawiz społy starych drzew w lesie, wyróżniające się młode drzewka lub nawet pojedyncze drzewo rosnące $w$ pobliżu zagrody.

W XIII-wiecznych chłopskich ogrodach uprawiano przede wszystkim rośliny użytkowe: kapustę i rzepę, które stanowiły podstawe wyżywienia chłopskiej rodziny, a także chmiel, którego owoce wchodziły w skład dziesięciny kościelnej. Uprawa Inu, prosa i innych zbóż miała miejsce w wiekach późniejszych. W średniowiecznych chłopskich sadach oraz na miedzach sadzono gtównie jabłonie i grusze. Nowe uprawy pojawiły się zarówno w rezydencjonalnych, jak i chłopskich ogrodach w XVI w., kiedy to do Polski przeniknęły wpływy ogrodnictwa włoskiego.

Elementy ozdobne $w$ chłopskich ogrodach pojawiły się pod koniec XVII i na początku XVIII w. pod wpływem znacząco rozwijających się w tym czasie ozdobnych ogrodów przy dworach, rezydencjach magnackich i posiadłościach kościelnych. Dużą rolę odegrało tutaj też uwłaszczenie. Przydzielone zabudowania ogradzano, a przed chałupami zaczęto zakładać przedogródki, zwane też ogródkami przedokiennymi. Stanowiły one element ozdobny chłopskiej zagrody. Wtedy też w chłopskich ogrodach pojawiają się zioła. Wcześniej zioła, stosowane głównie w celach leczniczych, spotkać można było prawie wyłącznie w ogrodach przyklasztornych. Ponadto, up a niektorych zioł w ogrodzie, mogla sciągnąc podejrzenia o uprawianie niedozwolonych praktyk. Powszechnośc i początków XIX w.

Rozpowszechnienie nasadzania krzewów ozdobnych w gospodarstwach chłopskich miało miejsce w XIX i XX w. Drzewa sadzono na skraju ogrodu i przy budynkach. Miały one zapewniać ochrone przed stońcem oraz chronić budynki w razie pożaru. Wiek XX, to dalszy rozwój chłopskich ogrow razie pożaru. Wiek XX, to dalszy rozwoj chłopskich ogro-
dów przydomowych, traktowanych jako swoista wizytówka dów przydomowych, traktowanych jako swoista wizytówka
mieszkańców zagrody, które niekiedy wyróżniały się charakmieszkancow zagrody, ktore niekiedy wyrożniały się charak-
terystycznymi regionalnymi cechami. Na Kurpiach były to terystycznymi regionalnymi cechami. Na Kurpiach były to
geometryczne rabaty i grządki, na Mazurach i Pomorzu układ geometryczne rabaty i grządki, na Mazurach i Pomorzu układ roslin był bardziej luzny i nawiązujący do nasadzen naturalistycznych, w Wielkopolsce obsadzone bukszpanem trawniki lub dywany kwiatowe w kształcie kwadratu z kołem w środku również obwiedzione strzyżonym bukszpanem, na Rzeszowszczyźnie powszechne były zgrupowania białych lilii na grządce lub przy ścianie budynku².

Jeszcze $w$ I połowie XX wieku stosunkowo rzadko w gospodarstwach wiejskich - na obszarze zagrody, obejścia czy też siedliska a nawet przydworskiego lub przypałacowego parku, sadzo- be distinguished in them, i.e. vegetables, herbs, an orchard and a grove'. It was the herbal garde garden and/or herbal garden located symm flower ly at the entrance to the plot. The orchard was the utilitarian part of the garden and formed a separate whole. A characteristic area of greenery around the house in the old days was a grove, also referred to
as a woodlet. The place, which was used for relaxa as a woodlet. The place, which was used for relaxa-
tion, was overgrown with grass and overshadowed by lime trees, oaks, ashes, sycamores or other trees and shrubs typical for the particular region. The term grove was also referred to various forms of
clusters of high greenery, which usually contained some magic contents. Those could be groups of old trees in the forest, some young trees standing out or even a single tree growing in the vicinity of the croft.
The plants grown in the $13^{\text {th }}$ century peasant gardens were above all utilitarian plants, i.e. cabbage
and turnip, which were the basic foods for the peasant family, and also hops the flowers of which were a part of the church tithe. Also flax, millet and other cereal crops were grown in later centuries. In that were planted in peasant orcherds. Near cree appeared both in the residential and the peasan homesteads in the $16^{\text {th }}$ century when the influence of Italian gardening spread into Poland.

Ornamental elements appeared in peasant gardens
in the late $17^{\text {th }}$ and early $18^{\text {th }}$ centuries under the in in the late $17^{\text {th }}$ and early $18^{\text {th }}$ centuries under the in-
fluence of the then rapidly developing ornamenta gardens at courts, stately homes and church es-
tates. A significant factor here was the abolition of serfdom. The allocated farms were fenced and forecottages; those were also referred to as 'in-frontof-the-window gardens'. They made a decorative element of the peasant croft. It was also then that herbs appeared in peasant gardens. In earlier times
herb, used mainly for healing purposes, could only be found in monastery gardens. Furthermore only ing some herbs in a garden might give rise to suspicions of being involved in prohibited practices. The commonness of foregardens is characteristic for th rural areas of the late $18^{\text {th }}$ and early $19^{\text {th }}$ centuries.
Planting ornamental shrubs at peasant farms be come widespread in the $19^{\text {th }}$ and $20^{\text {th }}$ centuries Trees were planted at the edge of the garden and outside buildings. They were intended to provide protection from the sunshine and to protect the further development of peasant kitchen gardens treated as a specific hallmark of the inhabitants
of the croft. Some of them were distinguished by of the croft. Some of them were distinguished by
their characteristic regional features. In the region their characteristic regional features. In the region
of Kurpie, they were geometric patterns of flowerbeds; in the Masurian and Pomeranian districts the plant design was rather loose and relating to natu-
ralistic plantings; in the region of Wielkopolska they were lawns with boxwood planted around them or
square-shaped flower carpets with a circle in the square-shaped flower carpets with a circle in the
middle, also edged with sculpted boxwood; in the Rzeszow region clusters of white lilies arranged in flowerbeds or along building walls were popular Still in the $1^{\text {st }}$ half of the $20^{\text {th }}$ century it was relative ly seldom that coniferous trees (except the pine)
were planted in rural developments - within the croft area, the farmyard or places of residence, o even in parks located by stately homes or palaces. of horror and danger, such as cemeteries and for-
ests. Sadly, coniferous trees and shrubs began to spread among the greenery growing round house no drzewa szpilkowe (z wyjątkiem sosny). Zarezerwowane były m.in. cmentarze i lasy. Drzewa i krzewy iglaste zaczeły niestety rozpowszechniać sie wśród przydomowej zieleni na obszarach wiejskich w II połowie XX w. Niestety, nie tylko dlatego, że takie nasadzenia są kulturowo obce, ale i pod względem użytkowym rośliny szpilkowe są niewskazane, a nawet niebezpieczne z uwagi na łatwość przenoszenia ognia w razie pożaru.

\section{Symbolika wybranych drzew i krzewów}

Cześć boska oddawano przede wszystkim drzewom. Wierzoróżnych sytuacjach życiowych. W kulturze ludowej drzen dzielono na żński" i opozycyine do nich "meski", poparte jest odpowiednim rodzajom grame nicrnym (meske: dab, buk, jawor ż́nske: lipa, brzoza, wierza, oska). Wy ózniano ówiez "dzewa przklete" - osika i wezba oraz blogosławione - lipa, leszczyna, brzoza, które mają dobroczynny wpływ na człowieka ${ }^{3}$.

Przypisywano poszczególnym drzewom specyficzne właściwości, które miały w rozmaity sposób oddziaływać na ludzi i ich losy. Za tajemnicze (świete) rodzind leby, lipy, klony, wiazy, brzozy, jesiony, buki, sosny, a nawe dęby, lipy, klony, wiązy, brzozy, jesiony, buki, sosny, a nawet topole i wierzby o duzych rozmiarach. $Z$ drzew nie rodzimych znajdowat się $w$ tej grupie przede wszystkim platan, miłorząb orzech Wloski. W kazdej dawnej zagrodzie musiało rosnąc chocby jedno stare drzewo, głównie lipa

celów Dęby i lipy uwazano za drzewa lepsze od inyedług ludowe tradycji, ukazywały się święte zjawy, a pod ich konarami czesto zawieszano czy tez ustawiano kapliczki ${ }^{4}$. Dąb łączono z symboliką męską a lipe z żeńską i bóstwami płodności ${ }^{5}$. Pod lipami (ale też i pod debami) świetowano i odbywano sady gdyż były one też symbolami szcześcia i spokoju ${ }^{6}$. Wierzono eż ż w lipie mieszka Matka Boska. Lipy wyznaczaty świeta przestrzeń i chronity świete źródta. Podobnie jak w przypadku debów nie można ich było rabać i palić. Takie zachowaby spetio

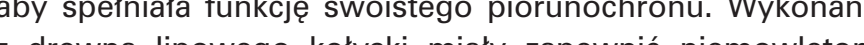
lipe wykolystywano takze w celach apotropeiczdobry sen. Lipe wy korysty majy zapewnic niemowe tom nych. Mhala stanowic najskuteczniejszy srodek na schwytanie i unieszkodliwienie rożnych demonow. Łyko lipowe służyło do unieszkodliwiania tak upiorow, jak i diabla. Obwiązywano nim krowie nogi, co mialo zabezpieczý zwierzęla przed czarami. Ta ochronna funkcja ujawnia się także pośrednio w zwyczaju stosowania lyka lipowego do wykonywania wianuszków swięconych w oktawę Bożego Clała. Słuzyły one do ochrony domu przed niebezpieczenstwem. Z kolei gałązki lipowe, korymi ozdabiano oltarze na drodze procesji Bożego Ciała zabierano do domu i zatykano w polu, co chronić miało gospodarstwa przed nieszczęściem. Odwiecznym zwyczajem było majenie chałup lipowymi gałęziami na Zielone Świątki. Gałęzie wisiały na domach do św. Jana, kiedy to wyschnięte spalano $w$ tradycyjnym sobotkowym ognisku ${ }^{8}$. in rural areas in the latter part of the $20^{\text {th }}$ century. The reason why this is sad is not only that suc

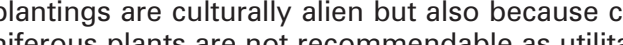
ian plants; they can actually be even dangerous 2. Symbolism of selected trees and shrubs It was above all trees that were worshipped. Peo-
ple believed in their supernatural powers, helpful to man in assorted life circumstances. In the folk culture, trees were divided into 'female' and opposing 'male' ones, which is supported by ap-
propriate grammatical gender (male: oak, beech, sycamore; female; lime tree, birch, willow, aspen, pen or willow, and blessed ones, such as lime tree or hazel, which have a beneficial effect on $\mathrm{man}^{3}$. Specific properties were ascribed to the particular
trees, which were supposed to have different efects on people and their fates. Indigenous trees considered mysterious (holy) were oaks, lime trees, elms, birches, ashes, beech trees, pines and
even poplars and large-sized birches. Non-indige-

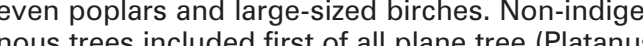
orientalis), ginkgo and walnut tree. Each croff of old would have at least one old tree, mainly lime tree or oak, which was supposed

Oaks and lime trees were considered to be trees petter than others for religious purposes. It was were seen according to the folk tradition, and it was common to place tree shrines under their branch-
es. The oak was associated with male symbolism and lime tree with female one and with gods of fertilitys. Lime trees (but also oaks) were the places for celebrations and judgements as they were also symbols of happiness and peace. It was also tected holy springs. Like in the case of oaks, they must not be chopped and burned. Such a behav iour was considered a sin?. It was thought that lime trees were never struck by lightning and therefor might serve as a specific replacement for a lightning conductor. Cradles made of lime tree wood were to ensure a good night's sleep to babies. It was supposed to be the most effective agosent catching and incapacitating various demons. Lim bark was used to incapacitate both phantoms and the devil. It was wrapped around cows' legs to tive function is also indirectly revealed in the custom of using lime bark to make wreaths that were consecrated during the Octave of Corpus Christi. They served to protect the household against danger. Lime twigs, in turn, which were used to decoutes, were taken home and stuck into the soil in
the field, which was meant to protect household against bad luck. An age-old custom was to adorn cottages with lime twigs for Pentecost. The twig dried out they were burned in the traditional celebratory bonfires

Oaks, which are often struck by lightning, were
due to this phenomenon considered already in the early Slavs' ceremonials as trees particularly dering Perun. The huge size, the extensiveness, 
Dęby, w które często uderzają pioruny były poprzez to zjawisko już w obrzędowości wczesnych Słowian uważane za drzewa szczególnie upodobane przez bóstwa niebios, na czele z gromowładnym Perunem. Wielkie rozmiary, rozłożystość, majestatyczność i długowieczność, a także twardość i trwatość drewna pozwalały widzieć w dębach symbol trwałości i nieśmiertelności. Wpływały na przekonanie o jego niezniszczalności. Jak już zaznaczono dębu nie wolno było ścinać, rąbać ani uszkodzić. Powinien on usychać powalony wiekiem, wo mogto sptonać tylko od oź biabieskiego"9. Wedtug wierzeń ludowych oparcie wać zdrowie a noszente w kieszenach żoledzi zabeziecato przed sarzenien to przed sarzenicm sie i pijanstwe potraf uśnienzýc ból zaponiegac ióny dolegliwosciom. Dąb wykazysy wan by takie do czanym doleglwosciom. liście wtykano w dom gospodarza, któremu źle życzono, aby sprowadzic na niego nieszczęście.

Bardzo pospolity w gospodarstwach chłopskich był niegdyś, ceniony w medycynie ludowej, czarny bez. Z uwagi na silne działanie bakteriobójcze, dobry wzrost w środowisku przenawożonym i specyficzny, nieprzyjemny zapach jego kwiatów szczególnie ulubiony przez owady, sadzono go koło ustępów, miejsc wylewania nieczystości i gnojowni.

Bez wiązano przede wszystkim ze sferą chtoniczną i domeną śmierci. W mitologii i przesądach utożsamiany był ze złem i dlatego sadzony z tyłu domu, aby chronit obejscie od czarownic i aby się "złe" nie zakradło. W całej Europie Srodkowej wierzono, że nie wolno palić bzem w piecu, bo taka czynnośc moze wywołac choroby skory. Bez nie był krzewem niszczonym, ale obdarzanym szacunkiem. (...) bzu wyrostego na ogrodzie wieśniak nie podkopuje nigdy ${ }^{11}$, a (...) gdzie bez rośnie, tam diabel mieszka. Bzu tedy wytępiać nie należy, gdyż wycinajacy bardzo tatwo na szkody wielkie narazić sie może ${ }^{12}$. Tylko wdowy i sieroty mogły go ścinać. Według wierzeń ludowych czarny bez petnitrole ap jego poświch onmi gatazka i domy i ptoty, aby zabezpiocza jeged chorobami i gradem. Wierzono, że magicza moc ma też miejsce pod mazie

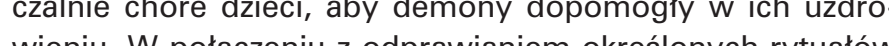
wieniu. W polączen in z odprawaniem okreslonych rytuałow

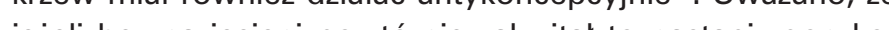
jeżen bez na jesiezi pow. gos młodego i lubianego. W celu uchronienia się przed taka ewent jarzębiny, aby odwrócic uwage demonow od żywych osób. Gdy wiosną kzew bez powodu mannia lub usychal znaczyło to, że będzie susza i zabraknie wody w studniach ${ }^{15}$.

\section{Rośliny ogródków przydomowyc}

Określone, symboliczne znaczenie przypisywano większości roślin sadzonych w przedogrodkach. Łączono je z obrzędowością religijną i ludową. Roża i tojad związane były z symboliką maryjna, bukszpan i bluszcz z misterium wielkanocnym. Na zakończenie oktawy Bożego Ciała wieszało się na ścianie domu święcone wcześniej wianki, w których można było znaleźć rozchodnik i macierzankę, które miały rozpędzać chmu- magnificence and longevity as well as the hardness and durability of the wood made oaks be perceive features contributed to the conviction of its indestructability. As already mentioned, it was not permitted to cut down, chop or damage oak trees. An oak should dry out and fall to pieces knocked down by the old age. Use of oak wood as a fuel was also
impermissible. Such a tree could only burn from "heavenly fire's. According to the folk beliefs, if you leaned against an oak in the spring, this would give you good health and carrying acorns in your pockets protected you form aging and drunkenness'
was also believed that oak could kill pain and Was also believed that oak could kill pain and pre-
vent various ailments. The oak was used in black magic, too. Dried leaves were stuck into the hous of a farmer who was ill-wished in order to bring misfortune upon him.

A very common plant grown by peasants was
black elderberry, which was treasured in folk medicine in the old days. Due to its strong antibacteria effect, good growth an overfertilised environment and a specific, unpleasant smell of tis flowers, Was particularly favoured by insects; it was planted ed and manure pits.

Elderberry was primarily associated with the chthonic sphere and the domain of death. In the mythology and superstitions, it was identified with ev
and therefore it was planted at the back of the house so that it should protect the yard against witches and keep the 'evil ones' at bay. In the whole Centra Europe, it was believed that one must not burn elderberry in an oven as such an activity might cause destroyed but respected....elderberry grown in the garden the peasant shall never dig", and ... where elderberry grows, the devil lives. Hence, elderberry should not be eradicated as he that cutteth can very and orphans were allowed to cut it down. According to the folk beliefs, black elderberry fulfilled the apotropaic role. Its sanctified twigs were used to decorate houses and fences so that it should proa spot beneath a crown of elderberry had a magic power, too. Mothers brought their terminally in children there so that demons might help in healing them. In connection with specified rites the shrub It was thought that if have a contraceptive effect autumn, then someone young and liked would die In order to avoid such an occurrence, rowanberry fruit was hung on blossoming elderberry at nigh so as to divert the demons' attention from livin a reason, it meant that there would be a drought and a shortage of water in the wells

\section{Backyard gardens plants
A specific, symbolic meaning}

of the plants that were grown was attributed to mos were associated with religious and folk ceremonials. The rose and the monkshood were related with Marian symbolism, the boxwood and the ivy with Easter
Drama. At the end of the Octave of Corpus Chris prama. At the end of the Octave of Corpus Chris ly consecrated wreaths, which included stonecrops and thymes, which were supposed to disperse hal clouds. Furthermore, the thyme was supposed to help women attract a husband and to boost exoon the Feast of the Assumption of the Blessed Vi- ry gradowe. Ponadto macierzanka miała pomagać kobietom wspomagać egzorcyzmy $y^{16}$. Swięcone na święto Matki Boskiej Zielnej oraz Boże Ciało bukiety zieln zawierające leszczyne, bylice boże drzewko i kopytnik, miały uchronić plony od nieszcześć burzowych i gradowych. Osobna grupe roślin stanowiły zioła świętojańskie: Julek czarny, topian, miẹta, dziurawiec, pokrzywa. Miały one chronić ludzi zwierzeta i plony przed urokami czarownic, chorobami i kleskami żywiołowymi17. Miete uznawano za symbol madrości gościnności i mitości, a dziurawiec miat chronić przed złymi lem (co ma uzazizeciwdepresyjnych). Ziow obrzedach ludowych wykorzystywane były na szeroka skalę, a gwarantującego miłość wybranka lubczyku nie mogło zabrakną́ w żadnym ogrodzie.

Bardzo rozbudowana jest symbolika róży. Odgrywa bardzo ważną rolę w symbolice chrześcijańskiej, a jej maryjna symbolika blisk jest polskiej toscinskiej, a jej maryjna symki Bozi Jedt polsiej tradycj, zwazzanej z kultem Mat$w$ tradycji i kulturze ludowej, a róża nie jest kwiatem bliskim polskiemu folklorowi. Odgrywała ona znaczną rolę przede wszystkim w obyczaju dworskim ${ }^{18}$. W ogrodach chłopskich to przede wszystkim lilia, fiołek i tojad prezentowały symbolike maryjna.

Wwielu rejonach Karpat tojad nazywany bywa "trzewiczkam Matki Boskiej". Wzięło się to stąd, że - jak głosi legenda podczas ucieczki Swiętej Rodziny przed Herodem, na próżno Maria prosila różne rosliny, by użyczyły Jej liści i kwiatów na obuwie, które uległo zniszczeniu. Tylko tojad ofiarował swoje niepozorne kwiaty. Od tamtej pory mają one niebieski maryjny kolor i zdolności odstraszania zła19. Wierzono, że tojad ułatwia rozpoznanie i zabicie wilkołaków oraz hybryd ${ }^{20}$. Ludowa nazwa tojadu: mordownik, nawiązuje do jego trujących właściwości.

Złe moce miały też odstraszać zawieszane na drzwiach wianki i stroiki robione z bukszpanu, który nieodłacznie kojarzy kie z Wielkanoca. Ze wzgledu na zawsze zielone liscie, ktore długo zachowujá swiezość po ścieciu, bukszan stat sie ry. W chrzćijański in mbolice oznacza nadzieje na zatutwychwstasie i wiare w nieskończoność życi. Zblizo zar-

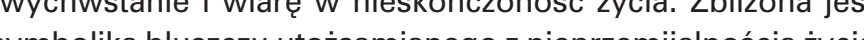
i wieczly przywiazaniem, zmazychws iniecznym przywi telnością dusz ${ }^{21}$

4. Symboliczne atrybuty roślin w ogródkach "panieńskich” Przed chatami, w których były panny na wydaniu w przedogródkach sadzono mirt, lilie, rozmaryn, malwy, rutę, wrotycz, nagietki i aksamitki. Wszystkie te rośliny miały nie tylko sym boliczne znaczenie, ale $z$ reguły praktyczne zastosowania, związane, wśród wielu innych, z kobietą, kobiecością i płodnością.

W starozytności mirt był rośliną poświęconą babilońskiej bogini milosci Isztar, greckiej Afrodycie czy rzymskiej Wenerze ${ }^{22}$. Poprzez powiązanie z Matką Boską, roślina stała się w chrześcijaństwie jednym ze znaków dziewictwa. Był symbolem czystości, ale i miłości oraz płodności. Dlatego też z jego gałązek gin Mary (which is referred to as the Feast of Our Lady of Herbs in the Polish tradition) and on Corwild ginger were intended to protect crops from the misfortunes of storms and hails. A separate group of plants were the midsummer herbs, i.e. the black henbane, burdock, mint, St. John's wort and netle. They were to protect people, animals and crops asters'". The mint was recognised as the symbol of wisdom, hospitality and love while St. John's wort was to protect against evil witchcraft and spells as well as against sorrow and grief (which is substanused in folk ceremonials on a large scale; and the lovage, which guaranteed the bridegroom's love, was a must in every garden.

The rose symbolism is very intricate. It plays a very in symbolism is close to the Polish tradition related to the cult of God's Mother. However, this motif is poorly represented in the folk tradition and culture, and the rose is not a flower closely associrole first of all in courtly customs ${ }^{\prime s}$, In peasants gardens, it was above all the lily, the violet and the monkshood that represented Marian imagery. In many regions of the Carpathians, the monkshood The origin of this phrase is related to a legend that. says that when the Holy Family were on the run fleeing from Herod, Maria asked various plants to lend her their leaves and flowers to replace her destroyed shoes albeit to no avail. It was only the
monkshood that offered its inconspicuous flowers. Ever since that time they have had the blue Marian colour and the ability to scare off evil spirits ${ }^{19}$. It was believed that the monkshood makes it easier to recognise and kill werewolves hybrids ${ }^{20}$. The folk name
of the monkshood, mordownik (old-fashioned to its poisonous properties. Evil powers were also to be scared off by the
wreaths and sprays made of boxwood, which is inherently associated with Easter. Due to its evcureen leaves that remain fresh a long time after ty and the perpetual rebirth of nature. In Christian symbolism, it points to the hope of resurrection the symbolism of the ivy which is identified with the infinite timelessness of life and the eternal attachment, resurrection and immortality of souls ${ }^{21}$.

4. Symbolic attributes of plants found in 'maiden' gardens

In foregardens outside the houses where there lived marriageable maidens, it was myrtle, lilies masemary, hollyhocks, rue, tansies, calendulas and not only have symbolic meaning, but they also had as a rule practical application related, among many In ancient times, the myrtle was a plant devoted to the Babylonian goddess of love, Ishtar, the Gree sociation with God's Mother the plant became one of the signs of virginity in Christianity. It was a symtwigs were used to plait wreaths or arrange flower bunches for brides in order to make sure they en myrtle is one of the few plants found in traditiona 
wito wianki lub wiązanki dla panien młodych, aby zapewnić im lu roślin spotykanych $w$ tradycyjnych zagrodach mirt w zasadzie nie posiada zastosowań praktycznych. Można przyjąć, że w budowaniu znaczenia symbolicznego mirtu znaczaca role odegrała właśnie ta jego praktyczna "bezużytecznośćc oraz intensywny, przywodzacy na myśl kadzidła i dymy ofiarne, zapach, który wydają roztarte liście rośliny.

Kwiatem weselnym, symbolizującym dziewictwo panny mbejej była rómiè lilia biała która w chrześcijástuie jest myodej by rón

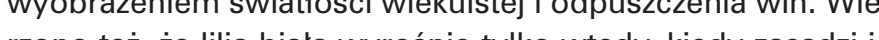
dobra kobieta lub też gospodyni będąca głową domu. dobra kobieta lub tez gospodyni będąca głową domu.
Głównym źródłem znaczeń przypisywanych rozmarynowi

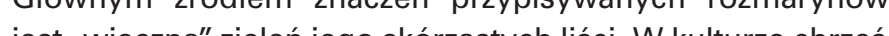

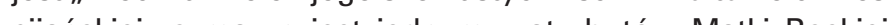

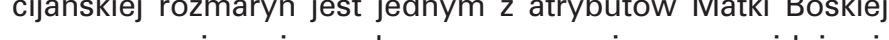
co oznacza, że w jego obszarze znaczeniowym znajduje się nieskalana czystośc i dziewictwo. Wultywowanych do dzisiaj polskich zwyczajach weselnych bukieciki z rozmarynu są
atrybutem druhen i drużbów. Przypina sie je także gościom weselnym. Symbolizująca dziewiczość roślina w ludowym językin symbolzuąca dziewiczosć roślína wiudowym ję miłości cielesnej. Jej liściom i gałazkom przypisywano właściwości pobudzajaj ciwości pobudzające erotycznie. Rozmaryn znajdowal zastonieńskiej, to odpowiednio użyty mógł rozpalać uczucia. Samo wąchanie rozmarynu miało sprowadzić miłość.

Tradycyjnie utożsamiana z malowniczością chłopskiej zagrody malwa, symbolizująca boleść i miłosierdzie, była znakiem prośby o przebaczenie. Nie ulega wạtpliwości, że taka symbolika wynikała z jej zastosowań, ściśle związanych z kobieca fizjologią.

$W$ tradycji ludowej $w$ wianek panny młodej wplatano również rutę. Przechowywany następnie $w$ małżeńskiej sypialni miał gwarantować szczęście i spokojne małżeństwo. Dziewczęta nigdy same nie siały ani nie sadziły ruty w ogródku, gdyż nie wyszłyby nigdy za maż. Dlatego o starych pannach mówiło się: że rutkę sieją. Staropanieństwo przepowiadał też listek ruty, używany w czasie wróżb andrzejkowych.

Rutę stosowano też przeciw rozmaitym demonom. Jej znaczenie apotropeiczne wynikało $z$ faktu, że jest ona jedną z roślin, których liście nie traca zieleni, maja gorzkie owoce i silny aromat. Z czasów Średniowiecza wywodzi sie wiara, że samo noszenie ruty chronić ma przed czarownicami i urokami. Pstrokate kwiaty miały odwracać "uroczny wzrok", dlaczego też dziewczęta przystrajały włosy kwiatami nagietka, piwonii lub właśnie ruty. WWikopolsce dziewczęta nosity na rękach bransolety z owoców ruty, co miało im zapewnić ochronę przed urokami. Ruty, wespół z innymi ziołami antydemonicznymi używano przeciw demonom (rusałkom, czartom), ktore ukazywać się miały pod postacią wiatru. Całoroczną ochronę bydła przed demonami miało zapewnić dodanie poświęconej ruty i opłatka do wigilijnego pokarmu. Chronic je miało także okadzanie aromatycznym dymem palonych gaiązek ruty. Zabieg ten, znany w wielu kulturach, stosowano profilaktycznie w sytuacjach, kiedy „złe moce" wykazywały szczególną aktywność (chodzi zwłaszcza o święta przejścia związane ze zmianami cyklu słonecznego). crofts that have no practical applications. It can be assumed that it was just its practical 'uselessnes' symbolic meaning as well as its intense odour it brings to mind incense and sacrificial smoke, released when its leaves are rubbed.

Another wedding flower, symbolising the bride's virginity, was the white lily, which in Christianity is of sins. It was also believed that a white lily would only grow if it had been planted by a good woman or a housewife being the head of a household. The main source of meanings attributed to the rose-
mary is the 'everlasting' green colour of its leathery
leaves. In Christian culture, the rosemary is one of the attributes of God's Mother, which means tha within its semantic field there is immaculate purity and virginity. In Polish wedding customs that are practiced even today small rosemary bouquets are
attributes of the bridesmaids and best men. Also wedding guests have them pinned on. The virginity-symbolising plant occurs in folk erotic language when talking about fulfilment of body love.
Its leaves and twigs were associated with erotically stimulating properties. The rosemary was applie love magic. Even though it was supposed to guard maiden purity, if appropriately used, it could ignite feelings. Just
enough to bring love.

Hollyhocks was traditionally identified with the picsymbolised anguish and mercy and was a sign petition for forgiveness. It is beyond any doubt tha such symbolism stemmed from their applications
closely related to the female

In folk tradition, the bride's wreath had some rue
plaited in it. It was then stored in the marital bedroom to ensure happiness and peaceful marriage. Girl never sowed or planted rue in the garden on their own as otherwise they would never get mar-
ried. Therefore, spinsters were said to 'sow rue'. Spinsterhood was also foretold by rue leaves used during traditional fortune-telling rituals on St. Andrew's Day.

The rue was also used against all sorts of demons.
Its apotropaic significance stemmed from the fact that it was one of the plants whose leaves never lose the green colour and have bitter fruit and a strong aroma. According to a belief that originates from mediaeval times, just carrying some rue with you Varicoloured flowers were supposed to divert the 'enchanting gaze' and therefore, girls would adorn their hair with flowers of the calendula, peony or just rue. In the region of Wielkopolska girls would which was intended to provide them with protection against witchcraft. The rue, along with other antidemonic herbs, was used against demons (undines, chorts), which were said to appear in the form of
wind. Addition of some consecrated rue and a piece of Christmas wafer to the food partaken on Christmas Eve would guarantee all year protection agains demons for the cattle. They were also supposed to be protected as a result of incensing with the smoke
of burnt rue twigs. This procedure, known in many of burnt rue twigs. This procedure, known in many
cultures, was applied prophylactically in situations when 'evil powers' were particularly active (espe-
cially in connection with solstice festivals related to the changes in the solar cycle).

ages, due to its antisedtic, dititional medicine for ages, due to its antiseptic, disinfecting and para-
siticidal effect, as well as stimulating and hallu-
Wrotycz wykorzystywany był od stuleci w medycynie ludowe tobójcze oraz pobudzające, halucynogenne i podobnie jak malwa, poronne. Prawdopodobnie z uwagi na tą ostatnia właściwość używany był w magii miłosnej. Dziewczyna, która chciała się odkochać powinna wykapać się w naparze wrotyczu. Również nagietkowi przypisuje się właściwości magiczne, któr są ściśle związane z jego praktycznymi, leczniczymi możliwoś ciami zastosowań - leczenie chorób kobiecych i zapobi poronieniom. Wysuszone plaki róliy kozypane pod pzy też wizżo pod poduszke w ptóciennym woreczoź piem cay tez whione pod podu kie lęki, zwidy i strachy. Nagietek w obrzędowości obyczajowe

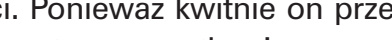
całe lato aż do póznej jesieni, a nawet na początku zimy, uz

Spotykana w "panieńskich” ogródkach aksamitka pełniła funkcję strojnego strażnika ogrodu. Olejki eteryczne i charaktery styczny ostry zapach aksamikki ograniczają rozwój chwastów odstrasza szkodniki (nicienie, slimaki, owady). Aksamitk symbolizuje bliskość i przede wszystkim nadzieję, co wywodzic należy z pierwo Ameryki Poludniowej aksamitki kwitną w okresie Dnia Wszys kich Swiętych. Dlatego tez określane są tam mianem „Flor de muero" - kwiatow smierci. Z takim przydomkiem trafity do Europy i tak się przyjęły w świadomości Europejczyków ${ }^{23}$.

\section{Podsumowanie}

Rosliny towarzyszyły ludziom w życiu codziennym i obchodach świątecznych nie tylko jako element wystroju. Pełnity w nich czesto wazne role dzieki przypisywanym im właściwościom. W artykule z 1895 r. czytamy, że: Lud uważa drzewa i kwiaty jako tylko czasowa cielesna ostone duszy, jako tylko dalsze miejsce tymczasowego zatrzymania sie. (.. Każde prawie drzewo jest dla wiéniaka naszego nic 列 już to korzyść, już to szkode przynosi. Z uszanowaniem i czcia spoglada wieśniak na kwiaty i drzewa, bo mniema, że one mieszkaniami duchów, bo mniema, że wyrzadziwszy jaka szkode drzewu, obrazi na sie i ducha zamieszkujacego je, któy nú kare za to zestać może. Każde drzewo wzbudza w nim otuche lub bojaźn stosownie do tego, w jakie wyobraźnia jego przybrała je przymioty, jakimi zaludnita duchami - dobrymi czy złymi24. Dawna głęboka wiara w magiczna moc roślin, która chroni, leczy, zapewnia urodzaj jest na tyle silna, że do dziś możemy spotkać się z jej reliktami. (...) wszystkie drzewa i rośliny,

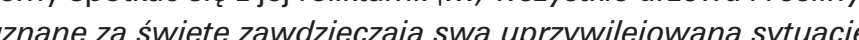
temu, ze wcielaja archetyp, wzorcowy obraz wegetacii. $Z$ drujej strony to wtaśnie wartość religijna sprawia, że jakaś roślgej strony to wiasnie wartosc religinna sprawia, ze jakas rosiwa jestoczona względami i uprawiana $a^{25}$. Tak więc skoro człowiek jest elementem przyrody, a rosliny towarzyszą ludziom od narodzin do smierci to nie powinien dziwić fakt częstego ich występowania $w$ dorocznych obrzędach. Były integralną częścią cyklu dorocznych świąt, wyrażając wiele symbolicznych ulegał zmianom to dotrwał do naszych czasów. cinogenic; and, like the hollyhock, abortive. It was probably because of that latter property that it was pre Also, the calendula is believed to have magic properties, which are closely related to its practical, medicinal application potential, such as healing female diseases and preventing miscarriages or placed under the pillow in a linen pouch wer supposed to ensure quiet sleep. And worn in a orange-coloured pouch at the height of the solar plexus would deter all sorts of anxieties, halluci-
nations and fears. In ceremonials related to the of joy. As it is in blossom throughout summer unt late autumn and even early winter, it was deemed a symbol of timelessness and eternal love, The tagetes, or marigold, found in the 'maiden' guardian of the garden. Its essential oils and characteristic sharp odour reduce the growth of weeds and repel pests (nematodes, snails, insects). The narigold symbolises closeness and above
hope, which must be derived from the primary symbolism of the area of origin. In countries South America marigolds blossom around All Saints' Day. For this reason, they are called there Flor de muerto', i.e. flowers of death. It was with and in such manner, they were adopted in the Europeans' awareness

5. Conclusion

lants accompanied people in their daily lives decoration. They often played important roles due to the properties attributed to them. In an article from 1895 we read that: Folks consider trees and
flowers as merely an interim bodily shield of the soul, as merely a further place of temporal stay
.. Nearly every tree is for our villager, as it were a sanctuary, a dwelling place of a ghost or a mysterious power that brings them either some benthit or some harm. It is with respect and reverence
the villager looks upon flowers and trees a they reckon that these are some ghosts' abodes as they reckon that if they do any harm to the tree then they might offend the tree and the spirit living punishment on the villager. Each tre stirs some couragement or fear in them depending on whic attributes their imagination adopted, what sort of spirits, good or evil, it is populated with ${ }^{24}$. The forcures, relics may be encountered even today.... all trees and plants deemed holy owe their privileged position to the fact that they embody an archetype, the it is due to the religious value that a certain plant is favoured and grown ${ }^{25}$. Thus, since man is a constituent of nature and plants accompany people from birth to death, then it should not be surprising that they commonly feature in annual celebraions. They were an integral part of the cycle of
annual festivals expressing a lot of symbolic contents. The association between plants and beliefs is so strong that despite having undergone some changes it has survived until our days. Greenery in the traditional peasant croft served three essential groups of functions, i.e. protective
and technical, utilitarian as well as social and cultur- 
W tradycyjnej chłopskiej zagrodzie zieleń spełniała trzy podstawowe grupy funkcji. Ochronno-techniczna, uzy kowa i społeczno-kulturowa. W ostatniej wymienionej grupie mieści sie symbolika roslin, ktora zachowywana i przekazywana jest w obyczaju i tradycji miejsca. Specyficzna symbolika roślin oraz ich "nadprzyrodzone" moce towarzyszyły człowiekowi na każdym etapie jego życia: od narodzin i czasu dzieciństwa, przez mał̇̇eństwo i dojrzałość, aż po starość i śmierć26. W przestrzeni siedliska wiejkiego znajdowaty miejsce i wyrażały sie dwie odwieczne i nierozerwalne wartości ludzkiego życia: i fory zo za

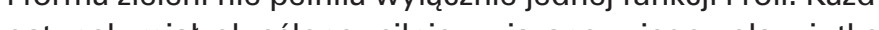
gatunek mik okrestone,

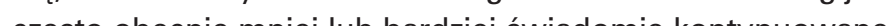
Pray czym obydwe warswy kuluy: religi i kaga, wcale sie Prey czym obydwie wa ws tu nie wykluczaly, a przeciwnie - wzajomie przenikaly i uzupetnialy codzlenne zycie wsi, tak indywidualne, jak i grupo$w^{28}$. Występujące lokalne roźnice symboliki roslin nie odbiegały od ogólnego jej znaczenia.

Wspołcześnie następuje niemal całkowity zanik tradycyjnych elementów ogrodu wiejskiego. Z uwagi na zmiany charakteru wsi, m.in. ich wielofunkcyjny rozwój funkcja użytkowa ustępuje miejsca ozdobnej oraz rekreacyjnej. Ginie regionalna tradycja i symbolika ogrodu wiejskiego - jego specyfika gatunkowa, kompozycyjna i funkcjonalna, a tym samym tożsamość krajobrazu wiejskiego. Tradycyjne, rodzime rośliny zastępowane są nowymi, niekiedy inwazyjnymi gatunkami. Następuje zanik ziół, ograniczanie gatunkow i ilości nasadzeñ na rzecz "praktycznych" trawników oraz drzew i krzewów iglastych. Jednakże, gdy w wielu miejscach na świecie przywraca się rodzimy charakter upraw i nasadzeń oraz promowana jest samowystarczalność żywieniowa istnieje szansa na powrót do wiejskich polskich ogrodów rodzimych gatunków roślin.

\section{ENDNOTES}

- Baranowski B. Zarys historii ogrodnictwa wiejskiego w Polsce. PWRiil. WarSzawa 1964 . Wessner H., Wiejski ogród przydomowy, Zakład Wydawniczy, CRS, Warszawa
1987 . 3 Marczewska M., Aspekty, wierzeniowe w rekonstrukcjii jezykowego obrazu
drzew, Acta Universitatis Wratislavensis, Jegzyk a kultura, t. 16, Wroctaw 2001, 5. 85.
4 Akademia Umiejettnósci, Kraków 1934, s. 531.
5 Kowalski P., Kultura magiczna. Omen, przesą, znaczenie, Warszawa 2007,

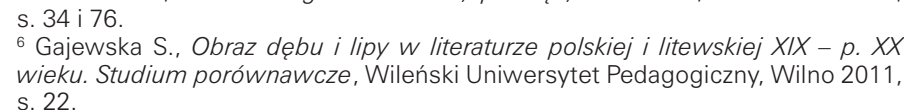
7 lbidem, s. 22.
8 Marszatie E., Lasy i drzewa w kulturze i wierzeniach, w: Gwiazdowicz D.J.,
Rykowski K., Dzziedzictwo. Lasy i gospodarka leśna w kulturze i dziedzictwie na-

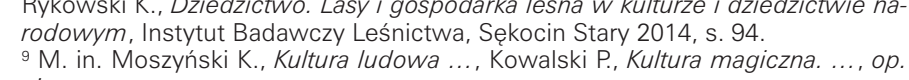
cit.
10 Marszatek E., Lasy i drzewa w kulturze ...., op. cit., s. 91-92.

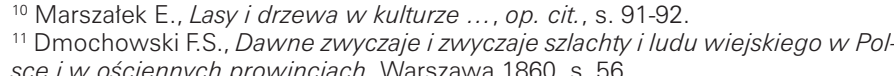

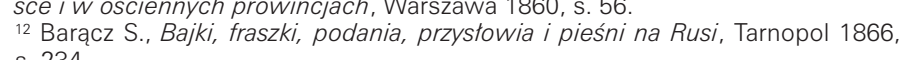
S. 234.
13 Kowalik A. Kosmologia dawnych Stowian, NOMOS, Kraków 2004, s. 347.
14 Zotadzż-Strzelczyk D., Dziecko w dawnej Polsce, Wydawnictwo Poznańskie, Poznnán 2006 So

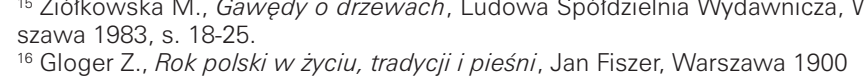

al. The latter mentioned group includes plant symcolism hat was preservod of plants and their 'supes of the' powics accolspanied man at every stage of their life, from birth and childhood, through the married life and maturity to old age and death ${ }^{26}$. Within the confinement of rura man life were present and manife values of the $h$ i.e. the sacred and the profane ${ }^{27}$, and none of the different species and forms of greenery served exclusively one function and role. Each species had a specific symbolic meaning within the realm of related to its utilitarian rule and often more closely consciously continued. The two layers of culture, religion and magic, were not mutually exclusive; quite on the contrary, they permeated and supplemented the daily rural life, both individual and collective divert from its universal meaning.

In modern times, the traditional elements of the rural garden have almost entirely vanished. Due to the ing its multifunctional development, the utilitari function gives way to the decorative and recreational ones. The regional tradition and the symbolism of the rural garden, its characteristic, compositionof the rural landscape, all of this is dying identity traditional indigenous plants are replaced with new sometimes invasive species. Herbs are disappeaing, the numbers of species and plantings are being reduced in favour of 'practical' lawns and conifein the world the indigenous character of crops and plantings is being restored and food self-sufficiency is being promoted, there is a chance of return to the ins plants.

ENDNOTES

'Baranowski B., Zarys historii ogrod
sce, PWBiL W Warszawa 1964 wiejskiego w Pot

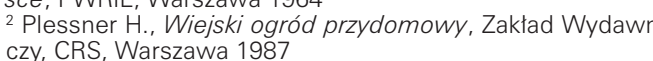
cZy, CRS, Warszawa 1987
3 Marczewska M. Aspeenty zykowego obrazu d drzew. Acta Universitatis Wratislavensis
J

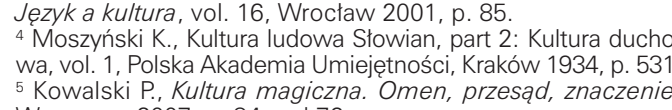
Warszawa 2007, p. 34 and 76

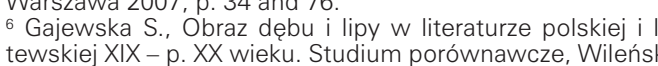
Universytet Pedagogiczny, Wilino 2011, p. 22.

8 Marszatek E.

G Marszatek E., Lasy i drzewa w kulturze i wierzeniach, w
Gwiazdowicz D.J., Rykowski K.,. Dziedzzictwo. Lasy i gospo

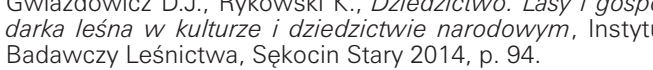
9
9

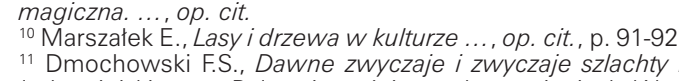
ludu wiejskiego w Polsce i w ościennych prowingjach. War-
szawa 1860 .

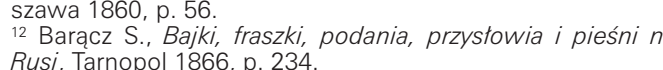
Rusi, Tarnopol 1866, p. 234 .
1 Kownalik A., Kosmologia dawnch Stowian, NOMOS, Kra-
KKo

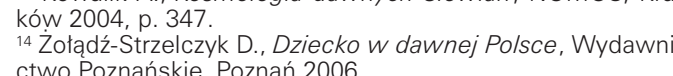

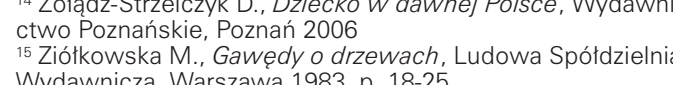

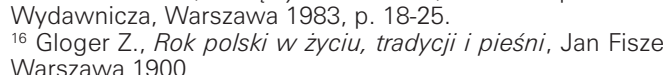

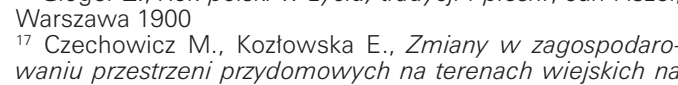
waniu przestrzeni przydomowych na terenach wiejskich na
przytadzie wsidolinoslaskich, w: Krajobraz i ogrod wiejski
vol. 2, Wyd. KUL, Lublin 2004

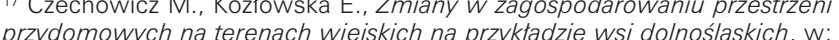

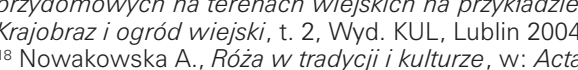
Universitatis Wratisla-

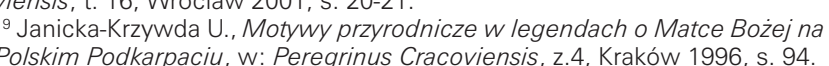
20 Baranowski B., W Wregu upiorów i wilkotaków, Wydawnictwo tódzkie, ${ }_{21}^{21}$ Wlodarc $2 y k$ Z., Rośliny biblijne. Leksykon, Instytut Botaniki PAN, Kraków ${ }_{22}^{2}$ Kopaliński Wt., Stownik mitó́ i tradycji kultury, PWZN, Lublin 1997
${ }_{23}$ Zielíski J., Symbolika roślin na cmentarzach, Przeglad Komunalny 08,

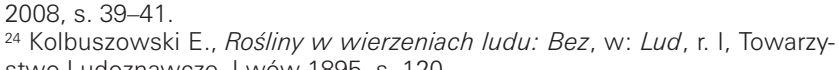

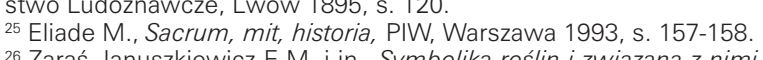

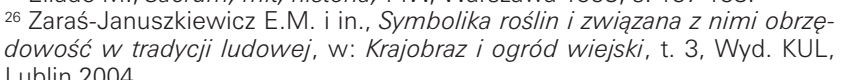
Gawryszewska B.J., Rola ogrodu frontowego w strukturze siedliska- stan 3. Wyd . KUL., Lublin 2004
${ }_{28}$ Sulima M., Sacrum i

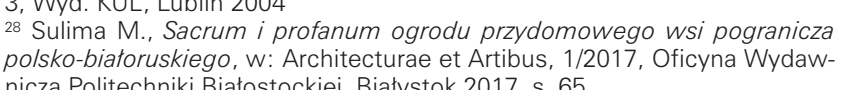

LITERATURA

[1] Baranowski B., Zarys historii ogrodnictwa wiejskiego w Polsce, PWRiL, [2] Baranowowski B., W kręgu upiorów i wilkotaków, Wydawnictwo tódzkie,

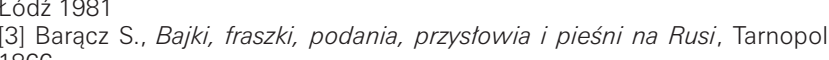
1866
[4] Czechowicz M., Koztowska E., Zmiany w zagospodarowaniu przestrzeni przydomowych na terenach wiejskich na przyktadzie wsi dolnosilaskich, w
Krajobraz i iogród wiejkk, t. 2, Wyd. KUL, Lublin 2004, s. 63-72.

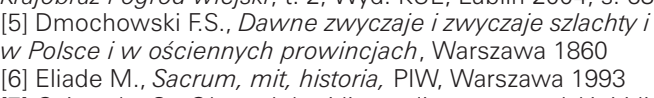

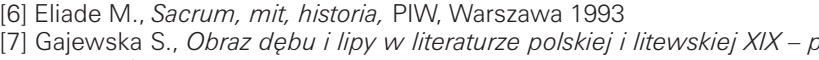

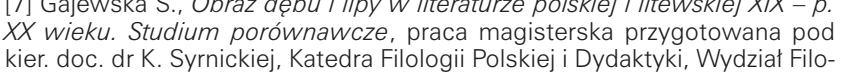
logiczny, Wileński Uniwersytet Pedagogiczny, Wilino 2011

stan wspótczesny a tradycja ogrodu wiejskiego, w: Krajobraz i ogród wiej-

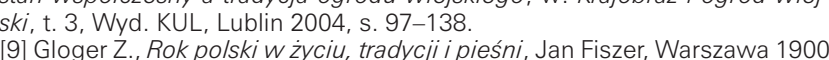

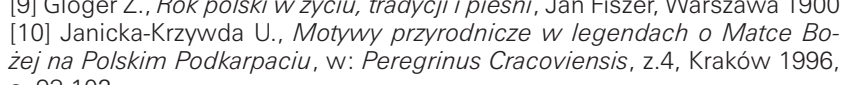
5. 93-102. Kolbuszowski E., Rośliny w wierzeniach ludu: Bez, w: Lud, r. I, Towarzy-

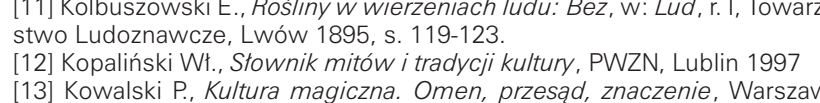
2007 Marzatek E., Lasy i drzewa w kulturze i wierzeniach, w: Gwiazdowicz
[14] M. Rykowski K, Dziedzictwo dzictwie narodowym, Instytut Badawczy Leśnictwa, Sęococin Stary 2014 ,

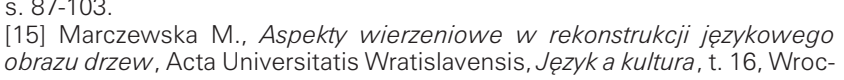

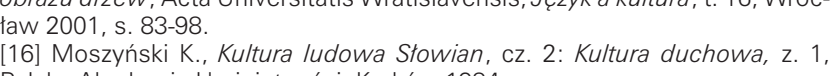
Polska Akademia Umiejętności, Kraków 1934 Nowakowska A., Róza w tradyciji kulturze, w: Acta Universitatis Wratis-

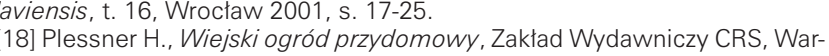
zawa 1987 . 119] W'odarczyk Z., Rośliny biblijne. Leksykon, Instytut Botaniki PAN, Kra-
ków 2011 Sulima M., Sacrum i profanum ogrodu prrydomowego wsi pogranicza
pol/sko-biatoruskiego, w: Architecturae et Artribus, 1/2017, Oficyna Wydaw-
nicza Politechniki Biatostockiej Białystok 2017. s. $63-70$. [20] Zarás-Januszkiewicz E.M., Szymczak-Piaték M. W. Wieczorek J., Symbo-

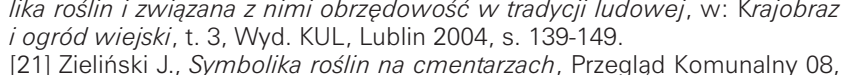
[21] Zielíński I., Symbolika roślin na cmentarzach, Przegląd Komunalny 08,
2008, s. 39-41.

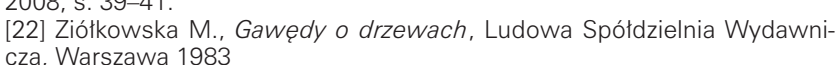
[23] Zotadzi-Strzelczyk D., Dziecko w dawnej Polsce, Wydawnictwo Poznań-
18 Nowakowska A., Roza w tradycll i kuturze, w: Acta Universitants

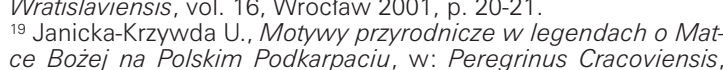

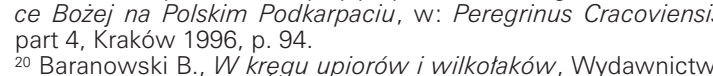

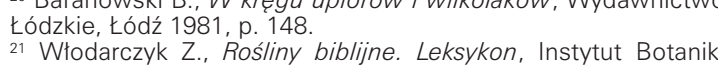

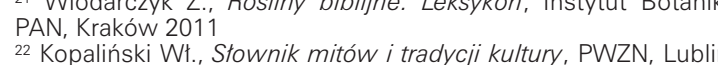
22 Kopalínski Wt., Stownik mitów i tradycji kultury, PWZN, Lublin
1997

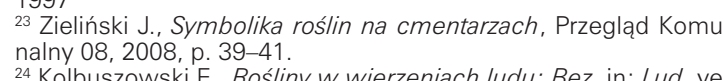

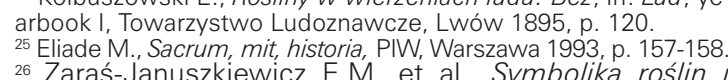

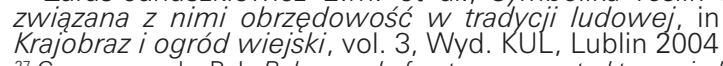
27 Gawryszewska B.J., Rola ogrodu frontowego w strukturze sied
liska - stan wsoótczesny a tradycja ogrodu wiejskiego, in: Krajo-

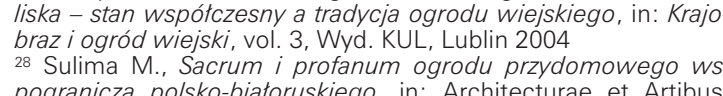

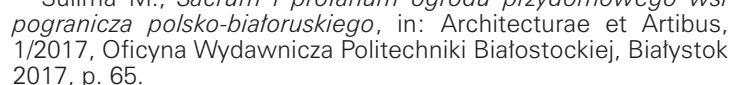
BIBLIOGRAPHY

[1] Baranowski B., Zarys historii ogrodnictwa wiejskiego W Pol
sce. PWRiL., Warszawa 1964

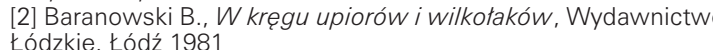
[3] Baragcz S., Bajki, fraszzki, podania, przystowia i pieśni na Rusi.
Tarnopol 1866 .

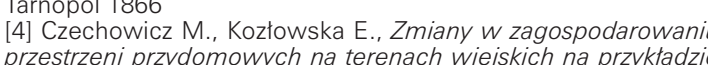
wsi dolnosilaskich, W: Krajobraz i ogród wiejski, vol. 2, Wyd. KUL,
Lublin 2004, p. 63-72.

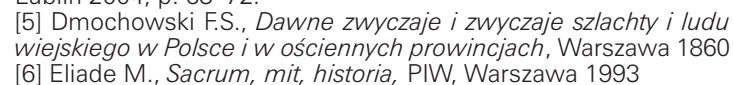
[7] Gajewska S. Obraz debui lipy w literaturze polskiej i litew
Skiei XXX - XX Wieku. Studium porónnawcre praca magister

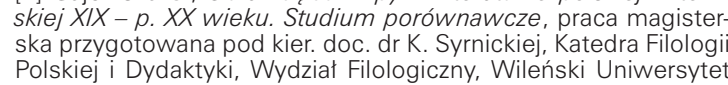

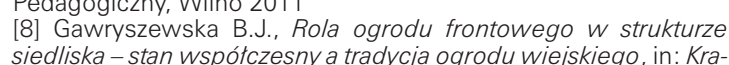

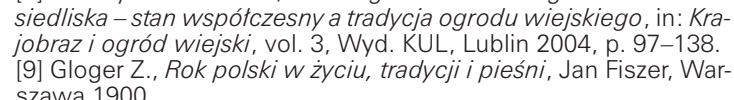
sawa gaco
11010 Janick-Krywda U., Motywy przyrodnicze $w$ legendach o
Matce Boziej na Polskim Podkarpaciu, in: Peregrinus Cracovien-

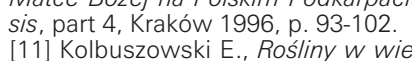

[11] Kolbuszowski E, Ros liny w wierzeniach ludu: Bez, in: Lud. [1121 Kopaliński Wt., Stownik mitón i tradycyil kultury, PWZN, Lublin Warszawa 2007 , Kultura magiczna. Omen, przesą, znaczenie. $[14]$ Marszatek E.. Lasy $i$ drzewa $w$ kulturze $i$ wierzeniach, in
Gwiazdowicz D.J.", Rykowski K., Dziedzictwo. Lasy i gospodarke

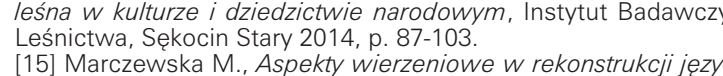

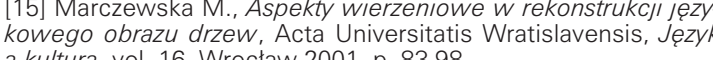
[16] Moszyński K.. Kulturara ludouna Stowian, vol. 2: Kultura ducho-

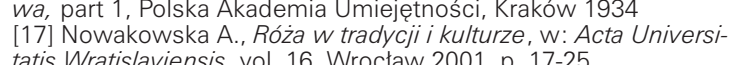

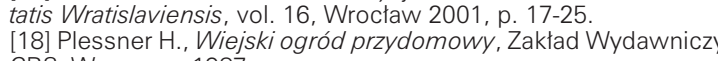

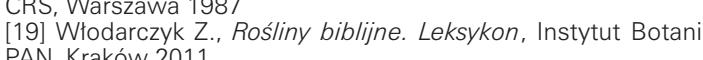

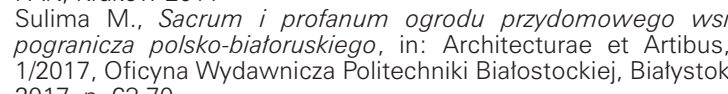

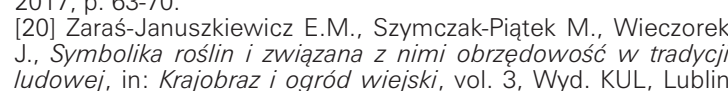

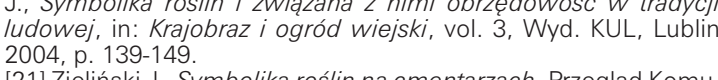

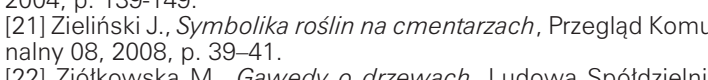

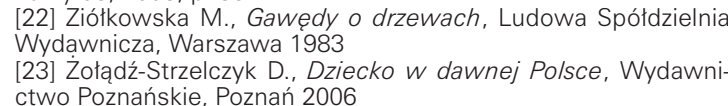

